\title{
Coffee Leaf Scorch Caused by a Strain of Xylella fastidiosa from Citrus
}

\author{
W.-B. Li, W. D. Pria, Jr., D. C. Teixeira, V. S. Miranda, A. J. Ayres, C. F. Franco, and M. G. Costa, Fundecit- \\ rus, Araraquara, 14807-040, SP Brazil; C.-X. He and P. I. Costa, Institute of Chemistry, UNESP, Araraquara, SP, \\ Brazil; and J. S. Hartung, USDA-ARS Beltsville, MD 20705-2350
}

\begin{abstract}
Li, W.-B., Pria, W. D., Jr., Teixeira, D. C., Miranda, V. S., Ayres, A. J., Franco, C. F., Costa, M. G., He, C.-X., Costa, P. I., and Hartung, J. S. 2001. Coffee leaf scorch caused by a strain of Xylella fastidiosa from citrus. Plant Dis. 85:501-505.

Citrus variegated chlorosis (CVC) and coffee leaf scorch (CLS) are two economically important diseases in Brazil caused by the bacterium Xylella fastidiosa. Strains of the bacterium isolated from the two plant hosts are very closely related, and the two diseases share sharpshooter insect vectors. In order to determine if citrus strains of $X$. fastidiosa could infect coffee and induce CLS disease, plant inoculations were performed. Plants of coffee, Coffea arabica 'Mundo Novo', grafted on Coffea canephora var. robusta 'Apuatão 2258' were mechanically inoculated with triply cloned strains of $X$. fastidiosa isolated from diseased coffee and citrus. Three months postinoculation, 5 of the 10 plants inoculated with CLS- $X$. fastidiosa and 1 of the 10 plants inoculated with CVC-X. fastidiosa gave positive enzyme-linked immunosorbent assay (ELISA) and/or polymerase chain reaction (PCR). Eight months postinoculation, another six plants inoculated with $\mathrm{CVC}-X$. fastidiosa gave positive PCR results. The two $X$. fastidiosa strains were isolated from the inoculated plants and showed the same characteristics as the original clones by microscopy, ELISA, and PCR. None of the plants inoculated with sterile periwinkle wilt (PW) medium as controls gave positive reactions in diagnostic tests, and none developed disease symptoms. Six months postinoculation, seven plants inoculated with CLS $-X$. fastidios $a$ and eight inoculated with CVC-X. fastidiosa began to develop characteristic CLS symptoms, including apical and marginal leaf scorch, defoliation, and reductions of internode length, leaf size, and plant height, terminal clusters of small chlorotic and deformed leaves, and lateral shoot dieback. We have demonstrated that $X$. fastidiosa from citrus plants is pathogenic for coffee plants. This has important consequences for the management of CLS disease and has implications for the origin of citrus variegated chlorosis disease.
\end{abstract}

Additional keywords: plant-pathogenic bacteria

Xylella fastidiosa (20) was first detected in coffee plants by serological tests (enzyme-linked immunosorbent assay [ELISA], dot immunobinding assay, and Western blot) and polymerase chain reaction (PCR) in São José do Rio Preto, São Paulo State, Brazil, in 1995 (14) and was demonstrated to be the causal agent of coffee leaf scorch (CLS) (10). Symptoms on affected coffee plants include shortened internodes, premature loss of older leaves, terminal clusters of small pale green to yellow deformed leaves, apical and marginal leaf scorch, lateral shoot dieback, reduction of fruit size and quantity, and

Corresponding author: J. S. Hartung

E-mail: Hartungj@ba.ars.usda.gov

* The $\boldsymbol{e}$-Xtra logo stands for "electronic extra" and indicates that figures in the on-line edition are in color, and the HTML abstract on-line contains supplemental material not included in the print edition.

Accepted for publication 12 January 2001.

Publication no. D-2001-0222-01R

This article is in the public domain and not copyrightable. It may be freely reprinted with customary crediting of the source. The American Phytopathological Society, 2001. chanical inoculation and to observe and describe CLS symptom development on coffee plants under controlled greenhouse conditions.

\section{MATERIALS AND METHODS}

Isolation and cultivation of strains of X. fastidiosa. Symptomatic leaves were collected from CVC-affected 'Pera' sweet orange (Citrus sinensis (L.) Osb.) grown in Taquaritinga, São Paulo, and coffee (Coffea arabica L.) cv. Mundo Novo grown at Matão, São Paulo. Leaves were disinfested and bacteria isolated from the petioles by attaching a syringe to the petioles and forcing sterile water through the xylem (11). Three to five drops of xylem extract were collected in culture tubes containing periwinkle wilt (PW) broth (4) that were incubated at $30^{\circ} \mathrm{C}$ and observed for microbial growth weekly. After X. fastidiosa had grown, usually 10 to 15 days after inoculation, the identity was confirmed by ELISA and PCR. The primary isolate from citrus was inoculated in Caipira sweet orange seedlings, which showed CVC symptoms 3 months after inoculation (8). The bacterium was reisolated from one of the symptomatic Caipira sweet orange seedlings and subcultured with the primary CLS isolate on PW agar plates until both strains were triply cloned. The final strains obtained from citrus and coffee were designated CVC-Xf2105 and CLS-Xf3124, respectively. These isolates were grown in liquid PW medium for several passages for pathogenicity tests in this work. At each passage, they were incubated at $30^{\circ} \mathrm{C}$ for 5 days. From one passage to another, $5 \mathrm{ml}$ of a saturated 5-day-old culture was transferred into $45 \mathrm{ml}$ of fresh PW medium. The procedures of isolation and culture described above were used for reisolation of the pathogen from coffee plants inoculated in this study.

Plant management and inoculation. Coffee seeds (Coffea canephora var. robusta L. 'Apuatão 2258' and Coffea arabica 'Mundo Novo') were collected from healthy trees and sown in sand. Fifty days after sowing, uniform seedlings of the two cultivars were selected, and Mundo Novo was top-grafted on Apuatão 2258. The grafted plantlets were transplanted into tubes containing commercial substrate PlantMax (Eucatex, São Paulo, Brazil) and grown for 5 months. Thirty uniform plants were selected and transplanted into pots (4 liters in volume) containing soil-based substrate $(60 \%$ subsoil, $17.5 \%$ composted 
bovine manure, $20 \%$ vermiculite) and grown for one additional month prior to inoculation.

The 8-month-old plants, each with five pairs of leaves, were not watered for 3 days prior to inoculation so as to become waterstressed to promote uptake of the liquid bacterial inoculum. A 7-day-old X. fastidiosa culture in liquid PW medium $\left(10^{8}\right.$ to $10^{9} \mathrm{CFU} / \mathrm{ml}$ ) was drawn into a syringe. Each plant was inoculated 20 times using a 22 gauge needle attached to the syringe to simultaneously wound the plant and supply inoculum. Ten plants were inoculated with CLS- $X$. fastidiosa clone 3124 (CLSXf3124), 10 plants with CVC-X. fastidiosa clone 2105 (CVC-Xf2105), and 10 additional plants were inoculated with $X$. fastidiosa-free liquid PW medium on 6 July 1999. All plants were maintained in a screen-protected greenhouse throughout the experiment to preclude unintended transmission of the pathogen by insect vectors.

Detection of $X$. fastidiosa in plant extracts. Bacterial detection was carried out for all the plants in the experiment using light microscopy (11), double antibody sandwich (DAS)-ELISA (2), and PCR (15). Xylem extracts were obtained for light microscopy from petioles by using a syringe to displace the xylem contents with sterile deionized water (11). The resulting drops of xylem extract were dried on glass slides, stained with methylene blue, and observed at $\times 400$ with a light microscope for the presence of bacilliform cells or their agglomerates typical of $X$. fastidiosa $(10,18,20)$.

Xylem extract was also collected and diluted 100-fold in deionized water (MilliQ, Bedford, MA). From this diluted ex- tract, $360 \mu \mathrm{l}$ was taken to a PCR tube and centrifuged for $12 \mathrm{~min}$ at $12,000 \times \mathrm{g}$. After the supernatant was removed, the pellet was dried for $10 \mathrm{~min}$ in a vacuum and resuspended in $10 \mu \mathrm{l}$ of deionized water. Primers specific for $X$. fastidiosa, 272-1-int and 272-2-int (15), were used for the PCR amplification.

The same plant samples that had been used for PCR were utilized for DASELISA (2) with a concentration of $5 \mu \mathrm{g}$ of IgG per $\mathrm{ml}$ for coating the ELISA plates (4 $\mathrm{h}$ at $37^{\circ} \mathrm{C}$ ) and with a 2,000-fold dilution of the alkaline phosphatase conjugated $\mathrm{IgG}$ $\left(4 \mathrm{~h}\right.$ at $\left.37^{\circ} \mathrm{C}\right)$.

Symptoms. When the plants were inoculated in their stems, they did not have branches. One month postinoculation, branches started to sprout. Branches were observed regularly for symptoms of the disease as it appears in the field $(10,14,16)$. Eight months postinoculation, the first five internode lengths from each of the four first branches on each plant were measured. The mean internode length from inoculated plants was compared with that obtained from healthy control plants. At the same time, measurements of the leaf width and length from the first five remaining leaves on each of the four branches used for the internode measurements, as well as the plant height, were taken to compare with those from healthy plants. The occurrence of leaf scorch, defoliation, chlorotic leaves, branches retaining only the most distal leaves, and shoot dieback were noted after inoculation.

\section{RESULTS}

Plant inoculations and diagnostic testing. In this study, Mundo Novo coffee

Table 1. Results of diagnostic tests for Xylella fastidiosa on coffee (Coffea arabica) 'Mundo Novo' plants inoculated with coffee leaf scorch, CLS-Xf3124, and citrus variegated chlorosis, CVC-Xf2105 strains of $X$. fastidiosa

\begin{tabular}{|c|c|c|c|c|c|}
\hline \multirow{2}{*}{$\begin{array}{l}\text { Inoculated } \\
\text { bacterium }\end{array}$} & \multirow[b]{2}{*}{ Plants } & \multicolumn{2}{|c|}{3 months postinoculation } & \multicolumn{2}{|c|}{8 months postinoculation } \\
\hline & & ELISA & PCR $^{\mathbf{a}}$ & $\mathbf{M S}^{\mathbf{b}}$ & PCR \\
\hline \multirow[t]{10}{*}{ CLS-Xf3124 } & 1,301 & - & - & - & - \\
\hline & 1,302 & + & + & + & + \\
\hline & 1,303 & + & + & + & + \\
\hline & 1,304 & - & + & - & + \\
\hline & 1,305 & - & - & - & - \\
\hline & 1,306 & - & - & - & - \\
\hline & 1,307 & + & + & + & + \\
\hline & 1,308 & - & + & + & + \\
\hline & 1,309 & - & - & - & - \\
\hline & 1,310 & - & - & - & - \\
\hline \multirow[t]{10}{*}{ CVC-Xf2105 } & 2,301 & - & - & + & + \\
\hline & 2,302 & - & - & + & + \\
\hline & 2,303 & - & - & + & + \\
\hline & 2,304 & - & - & - & - \\
\hline & 2,305 & - & - & + & + \\
\hline & 2,306 & - & - & + & + \\
\hline & 2,307 & - & - & - & + \\
\hline & 2,308 & - & - & - & - \\
\hline & 2,309 & - & - & - & - \\
\hline & 2,310 & - & + & + & + \\
\hline
\end{tabular}

${ }^{a}$ Primers used for polymerase chain reaction (PCR) were 272-1-int and 272-2-int; + means that a 600-bp DNA product characteristic of $X$. fastidiosa was obtained (15).

${ }^{\mathrm{b}}$ Light microscopy.

plants inoculated with both CLS-Xf3124 and CVC-Xf2105 did not show any definitive CLS symptoms 3 months after inoculation. We then performed diagnostic tests for $X$. fastidiosa by ELISA and PCR, using the first two mature leaves on the stem from each plant. Three plants inoculated with CLS-Xf3124 gave positive ELISA and PCR reactions, and two others were positive only by PCR (Table 1). None of the plants inoculated with CVC-Xf2105 gave positive ELISA reactions 3 months postinoculation, but one of them, plant 2310, yielded a positive PCR result. None of the control plants inoculated with liquid PW medium gave positive ELISA or PCR reactions.

Plants that tested positive by ELISA or PCR at 3 months postinoculation as well as some additional plants began to show CLS symptoms, including apical and marginal leaf scorch, leaf chlorosis, and defoliation, 6 months postinoculation (Table 2). The symptoms became strong by 8 months postinoculation, and the plants were tested again for $X$. fastidiosa by light microscopy and PCR (Table 1). Xylella-like, rodshaped bacteria were observed by light microscopy in four of the five plants inoculated with CLS-Xf3124 that had given positive PCR results during the first testing 5 months before. All five of these plants gave positive $\mathrm{PCR}$ reactions again during the testing at 8 months postinoculation (Table 1). Plant 2310 was inoculated with CVC-Xf2105 and gave a positive PCR reaction during the testing at 3 months postinoculation and also produced positive results by both light microscopy and PCR amplification. Xylella-like bacteria were also observed in another five plants inoculated with CVC-Xf2105, and the identity of the bacteria was confirmed by PCR. In summary, at 8 months postinoculation, $X$. fastidiosa could be detected in 5 of 10 plants inoculated with the coffee strain and 7 of 10 plants inoculated with the citrus strain (Table 1). The symptom severity, as measured by the reduction of internode length, leaf size, and plant height, was also similar for the two strains, ranging from 9 to $20 \%$ (Table 2). None of the control plants gave positive reactions through light microscopy or PCR during the diagnostic testing at 8 months postinoculation.

Symptom development. Symptoms of the CLS disease were consistent with those described in field conditions $(10,14,16)$ (Table 2). At 3 months postinoculation, although leaves of plants inoculated with CLS- or CVC-X. fastidiosa became increasingly chlorotic compared with leaves on control plants, no other CLS symptoms were observed. At 6 months postinoculation, some plants inoculated with CLS3124 began to show leaf scorch, which usually started at apical foliar parts and then extended to marginal regions. The same leaf scorch symptom also was observed in some plants inoculated with 
CVC-Xf2105 a short time later. Defoliation started 2 to 3 weeks after leaf scorch was observed and was rapid in the following 2 to 4 weeks. During this period, one to two leaves could be collected on the soil of each pot per day.

Because of defoliation, some branches retained only their most distal leaves. Such branches (Fig. 1) are called tufts (tufos in Portuguese). Leaves on tufts were closely spaced and were typically small, pale green to yellow, chlorotic, deformed, and scorched when they matured. In extreme cases, symptoms progressed to dieback of the entire shoot. Both internode lengths and leaf sizes were reduced, and the plants were stunted while the defoliation was in progress. In severe cases when young branches were defoliated, they developed in a zigzag course.

Among the 10 plants inoculated with CLS-Xf3124, the five plants that gave positive PCR reactions 8 months postinoculation showed reduced internode length, leaf size, and plant height, as well as leaf scorch, defoliation, and leaf chlorosis. Two of the five plants developed tufts on branch tips, and shoot dieback occurred on one plant (plant 1302). Three plants (1301, 1306, and 1309) that did not test positive for $X$. fastidiosa also did not show any CLS symptoms.

Among the 10 plants inoculated with CVC-Xf2105, all of the seven plants that tested positive for presence of $X$. fastidiosa by PCR analysis, performed 8 months postinoculation, showed reduced internode length, leaf size, and plant height, as well as leaf scorch, defoliation, and leaf chlorosis. Five of these seven plants also developed tufts on branch tips, and two of them had symptoms of shoot dieback. None of the control plants inoculated with liquid PW medium showed CLS symptoms or gave positive results in any of the diagnostic tests.

The symptoms of CLS disease on coffee Mundo Novo caused by CVC-Xf2105 were the same as those caused by CLSXf3124. Some of the plants inoculated with CLS-Xf3124 or CVC-Xf2105 showed these symptoms, but $X$. fastidiosa was not detected by ELISA, light microscopy, and PCR. This was probably due to either the sensitivity of these diagnostic methods or plant extracts that interfered with the diagnostic tests (W.-B. Li, unpublished).

Morphological, serological, and PCR comparison. No morphological differences were observed between the two primary isolates from which the clones CLSXf3124 and CVC-Xf2105 were obtained, clones CLS-Xf3124 and CVC-Xf2105, and clones CLS-Xf3124 and CVC-Xf2105 after reisolation from coffee plants inoculated in this work. All of the bacterial suspensions above reacted with an antiserum against CVC- $X$. fastidiosa (9) and yielded a band of 600 bp $(10,15)$ after PCR amplification with primers specific (272-1-int and 272-2-int) for X. fastidiosa (15).

\section{DISCUSSION}

The Pierce's disease strain of $X$. fastidiosa has long been known to have an exceptionally broad host range, and the alternate hosts can serve as inoculum sources for transmission to vineyards by sharpshooter insect vectors (5). Symptoms

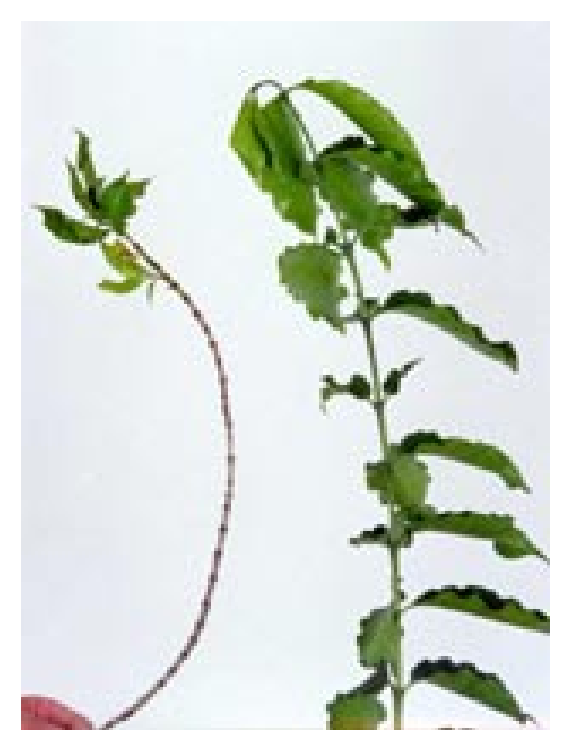

Fig. 1. Symptoms of coffee leaf scorch (CLS) on naturally infected coffee (Coffea arabica) 'Mundo Novo'. Right: healthy branch; left: affected branch with symptoms of shorter internodes, premature loss of older leaves, tufts of small deformed leaves, and apical and marginal leaf scorch.

Table 2. Symptoms of coffee leaf scorch on coffee (Coffea arabica) 'Mundo Novo' plants inoculated with CLS-Xf3124 and CVC-Xf2105 of Xylella fastidiosa

\begin{tabular}{|c|c|c|c|c|c|c|c|c|c|c|}
\hline \multirow{2}{*}{$\begin{array}{l}\text { Bacterium } \\
\text { inoculated }\end{array}$} & \multirow[b]{2}{*}{ Plant } & \multicolumn{4}{|c|}{ Reduction $(\%)^{\mathrm{a}}$} & \multicolumn{5}{|c|}{ Occurrence of symptoms ${ }^{b}$} \\
\hline & & IL & $\mathbf{L W}$ & $\mathbf{L L}$ & PH & $\mathbf{L S}$ & DF & $\mathbf{C L}$ & BDL & SDB \\
\hline \multirow{12}{*}{ CLS-Xf3124 } & $1,301(-)^{\mathrm{c}}$ & 0.6 & 0.2 & 0.1 & 0.2 & - & - & - & - & - \\
\hline & $1,302(+)$ & 20.1 & 18.4 & 19.1 & 20.2 & + & + & + & + & + \\
\hline & $1,303(+)$ & 18.8 & 16.3 & 16.2 & 17.8 & + & + & + & + & - \\
\hline & $1,304(+)$ & 18.6 & 15.8 & 15.4 & 16.8 & + & + & + & - & - \\
\hline & $1,305(-)$ & 11.5 & 10.2 & 10.5 & 11.0 & + & + & - & - & - \\
\hline & $1,306(-)$ & 0.5 & 0.2 & 0.3 & 0.5 & - & - & - & - & - \\
\hline & $1,307(+)$ & 17.8 & 17.2 & 16.5 & 18.0 & + & + & + & + & - \\
\hline & $1,308(+)$ & 15.4 & 14.8 & 15.0 & 16.0 & + & + & + & - & - \\
\hline & $1,309(-)$ & 0.8 & 0.2 & 0.3 & 0.4 & - & - & - & - & - \\
\hline & $1,310(-)$ & 18.1 & 17.5 & 16.8 & 17.5 & + & + & + & - & - \\
\hline & Mean & 12.2 & 11.1 & 10.2 & 11.8 & & & & & \\
\hline & Total $^{\mathrm{d}}$ & & & & & 7 & 7 & 7 & 3 & 1 \\
\hline \multirow[t]{12}{*}{ CVC-Xf2105 } & $2,301(+)$ & 13.8 & 13.2 & 12.5 & 12.8 & + & + & + & + & - \\
\hline & $2,302(+)$ & 10.4 & 9.8 & 10.0 & 9.2 & + & + & + & - & - \\
\hline & $2,303(+)$ & 15.4 & 15.2 & 14.7 & 16.0 & + & + & + & + & + \\
\hline & $2,304(-)$ & 0.4 & 0.2 & 0.3 & 0.5 & - & - & - & - & - \\
\hline & $2,305(+)$ & 16.2 & 15.8 & 15.5 & 15.7 & + & + & + & + & + \\
\hline & $2,306(+)$ & 14.3 & 13.9 & 14.0 & 13.5 & + & + & + & + & - \\
\hline & $2,307(+)$ & 13.2 & 12.8 & 11.5 & 12.0 & + & + & + & - & - \\
\hline & $2,308(-)$ & 0.5 & 0.2 & 0.2 & 0.4 & - & - & - & - & - \\
\hline & $2,309(-)$ & 13.3 & 12.1 & 11.9 & 12.4 & + & + & + & - & - \\
\hline & $2,310(+)$ & 14.4 & 13.8 & 13.4 & 14.2 & + & + & + & + & - \\
\hline & Mean & 11.2 & 10.7 & 10.4 & 10.7 & & & & & \\
\hline & Total $^{\mathrm{d}}$ & & & & & 8 & 8 & 8 & 5 & 2 \\
\hline
\end{tabular}

${ }^{a}$ Percent reduction compared with control plants inoculated with growth medium only. IL: internode length; LW: leaf width; LL: leaf length; PH: plant height.

${ }^{\mathrm{b}}$ Occurrence of symptoms typical of coffee leaf scorch disease. LS: leaf scorch; DF: defoliation; CL: chlorotic leaves; BDL: branches retain only the most distal leaves; SDB: shoot dieback.

${ }^{\mathrm{c}}$ Plant positive or negative for the presence of $X$. fastidiosa by diagnostic tests (enzyme-linked immunosorbent assay, polymerase chain reaction, light microscopy).

${ }^{\mathrm{d}}$ Number of plants displaying symptoms out of 10 inoculated plants. 
of almond leaf scorch and Pierce's disease can be induced by the same strains (13), and there is good evidence that plum leaf scald and phony peach disease have a common etiology (21). However, strains of $X$. fastidiosa from American elm (Ulmus americana L.) and sycamore (Platanus occidentalis L.), trees that occur close together in landscape settings, were pathogenic only on the host from which they were isolated, and not in the alternate host after reciprocal inoculations (19). Because citrus and coffee are widely grown in adjacent plantations in São Paulo, the possibility of reciprocal pathogenicity of the strains has been an urgent research priority.

We have shown here that a citrus strain of $X$. fastidiosa that causes CVC disease can also cause CLS disease when inoculated into coffee plants. The general inoculation efficiency of the citrus and coffee strains into coffee Mundo Novo was similar. Although both of the bacterial clones were pathogenic in coffee plants and caused the same disease symptoms, the multiplication rate of the bacteria in planta may have been greater for the coffee strain than for the citrus strain. CLS-Xf3124 was initially more readily detected by both ELISA and PCR than was CVC-Xf2105. It was also easier to isolate CLS-Xf3124 than CVC-Xf2105 from inoculated coffee plants, consistent with the idea of higher population levels with the coffee isolate in coffee (W.-B. Li, unpublished). Differential multiplication of $X$. fastidiosa after mechanical inoculation into hosts of differing susceptibility has been reported (6).

Previous work has shown that isolates of $X$. fastidiosa from citrus are morphologically, serologically, and genetically closely related to those from coffee plants $(3,10,14,17)$. This finding is consistent with the history and distribution of both diseases. In spite of the fact that the citrus strains were described before the coffee strains $(1,14,18)$, the following facts are
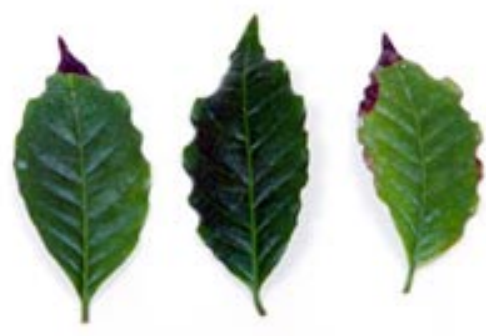

Fig. 2. Apical and marginal scorch of coffee leaves on artificially inoculated coffee (Coffea arabica) 'Mundo Novo'. Leaf on left: from a plant inoculated with clone CVC-Xf2105 of Xylella fastidiosa from citrus and exhibiting apical leaf scorch and normal shape; middle: from a healthy plant treated with PW medium; and right: from a plant inoculated with clone CLS-Xf3124 of Xylella fastidiosa from coffee and exhibiting apical and marginal leaf scorch and abnormal shape. consistent with the hypothesis that $X$. fastidiosa in citrus originated as a selection(s) from a pre-existing population in coffee. First, a disease with symptoms consistent with those described here for CLS and attributed to nematodes has been present in coffee plantations in Brazil much longer than the CVC disease (12). Many coffee plantations were abandoned because of the disease in various regions in Brazil 30 years ago, and sometimes the land was replanted with citrus. Second, the CLS disease has been found in coffee plantations in other states of Brazil where there has never been citrus cultivation. Third, the incidence of the CLS disease is much higher than that of the CVC disease in Brazil. Currently, CVC has affected 35\% of citrus plants in São Paulo State; however, it is very difficult to find any coffee plantations free of $X$. fastidiosa in São Paulo. Fourth, we have shown in this work that a strain of $X$. fastidiosa from citrus can cause coffee leaf scorch disease. All of the above are consistent with the idea that $X$. fastidiosa has long been well-adapted in coffee plants in Brazil and was more recently transmitted by sharpshooter insect vectors to citrus plants, where at least some strains have retained their pathogenicity to coffee.

The potential transmission of $X$. fastidiosa from citrus trees to coffee plants is a practical concern in São Paulo, Paraná, and Minas Gerais, states of Brazil, where coffee and citrus are planted together in many farms. In these regions, nurseries of coffee plants are in open air, without screens to offer protection from sharpshooter insects. Some of these nurseries are very close to CVC-contaminated citrus orchards. Preliminary results indicate that sharpshooters Oncometopia facialis and Dilobopterus costalimai can transmit $X$. fastidiosa from CVC-contaminated citrus trees to coffee plants (P. Yamamoto, unpublished).

To our knowledge, this is the first time that CLS symptom development on artificially inoculated coffee plants in controlled greenhouse conditions has been described in detail. This is important because each of the symptoms of the CLS disease, if taken separately, can be easily confused with those caused by other factors (16). For example, leaf scorch could be caused by low temperature or by deficiency and excess of potassium. However, leaf scorch caused by low temperature starts on young leaves and extends to semimature to mature leaves, the reverse of what is observed in CLS disease. Leaf scorch caused by deficiency or excess of potassium usually initiates from leaf margins, whereas leaf scorch caused by $X$. fastidiosa starts at the apical region of mature leaves. In the present work, leaves that abscised with only apical leaf scorch usually had a normal leaf shape, but those dropping with marginal leaf scorch were often deformed (Fig. 2).
This leaf deformation can be used to distinguish leaf scorch and defoliation caused by the CLS disease from those induced by other factors, such as water stress and leaf miner, since the leaves with scorch and defoliation caused by other factors are usually normal in shape. Short internodes could be caused by zinc deficiency. However, zinc deficiency makes only some internodes shorter, while $X$. fastidiosa makes all internodes shorter. Other symptoms of CLS, such as reduction of plant vigor and defoliation, can also be brought about by soil water stress, nematodes, nutrition deficiency, other diseases, or insects. The factors mentioned above should be carefully managed during a pathological trial on $X$. fastidiosa with coffee plants. Also, symptoms of CLS may be masked by other factors in field conditions, and symptom development on other coffee cultivars may well be qualitatively different from those described here for Mundo Novo.

Experiments to determine whether coffee strains of $X$. fastidiosa are pathogenic on citrus are underway at this time (W.-B. $\mathrm{Li}$, unpublished), and the results reported here give this work further impetus.

\section{ACKNOWLEDGMENTS}

Funding to support this research was provided as grant number $99 / 04345-3$ of the functional genome project of FAPESP (Fundação de Amparo à Pesquisa do Estado de São Paulo). We thank N. G. Fernandes, O. Paradelo Filho, L. O.S. Berian for useful suggestions; and C. Motta, R. R. Palma and C. R. T. Costa for technical assistance.

\section{LITERATURE CITED}

1. Brlansky, R. H., Davis, C. L., Timmer, L. W., Howd, D. S., and Contreras, J. 1991. Xylemlimited bacteria in citrus from Argentina with symptoms of citrus variegated chlorosis. (Abstr.) Phytopathology 81:1212.

2. Chang, C. J., Garnier, M., Zreik, L., Rossetti, V., and Bové, J. M. 1993. Culture and serological detection of the xylem-limited bacterium causing citrus variegated chlorosis and its identification as a strain of Xylella fastidiosa. Curr. Microbiol. 27:137-142.

3. Costa, P. I., Franco, C. F., Miranda, V. S., Teixeira, D. C., and Hartung, J. S. 1999. Strains of Xylella fastidiosa rapidly distinguished by arbitrarily primed-PCR. Curr. Microbiol. 40:279-282.

4. Davis, M. J., Raju, B. C., Brlansky, R. H., Lee, R. F., Timmer, L. W., Norris, R. C., and McCoy, R. E. 1983. Periwinkle wilt bacterium: Axenic culture, pathogenicity, and relationships to other Gram-negative, xylem inhabiting bacteria. Phytopathology 73:15101515.

5. Freitag, J. H. 1951. Host range of the Pierce's disease virus of grapes as determined by insect transmission. Phytopathology 41:920934.

6. Fry, S. M., and Milholland, R. D. 1990. Multiplication and translocation of Xylella fastidiosa in petioles and stems of grapevine resistant, tolerant, and susceptible to Pierce's disease. Phytopathology 80:61-65.

7. Hartung, J. S., Beretta, M. J. G., Brlansky, R. H., Spisso, J., and Lee, R. F. 1994. Citrus variegated chlorosis bacterium: Axenic culture, pathogenicity, and serological relationships with other strains of Xylella fastidiosa. Phytopathology 84:591-597. 
8. Li, W. B., Ayres, A. J., Miranda, V. S., Teixeira, D. C., Coutinho, A., Zavatti, E. R., and Palma, R. R. 1999. Patogenicidade de Xylella fastidiosa, agente causal da clorose variegada dos citros em laranja doce. Fitopatol. Bras. 24(supl.):260.

9. Li, W. B., Zreik, L., Fernandes, N. G., Miranda, V. S., Teixeira, D. C., Ayres, A. J., Garnier, M., and Bové, J. M. 1999. A triply cloned strain of Xylella fastidiosa multiplies and induces symptoms of citrus variegated chlorosis in sweet orange. Curr. Microbiol. 39:106-108.

10. Lima, J. E. O., Miranda, V. S., Hartung, J. S., Brlansky, R. H., Coutinho, A., Roberto, S. R., and Carlos, E. F. 1998. Coffee leaf scorch bacterium: Axenic culture, pathogenicity, and comparison with Xylella fastidiosa of citrus. Plant Dis. 82:94-97.

11. Lima, J. E. O., Miranda, V. S., Roberto, S. R., Coutinho, A., Palma, R. R., and Pizzolitto, A. C. 1997. Diagnose da clorose variegada dos citros por microscópio ótica. Fitopatol. Bras. 22(3):370-374

12. Matiello, J. B., Almeida, S. R., Garcia, A. W. R., Miguel, A. E., Períne, J., Araujo, M. M.,
Coabrile, C. A., Miranda, V. S., and Manfio, G. P. 1998. Levantamento da ocorrência do amarelinho em regiões cafeeira do Brasil e primeira constatação em cafeeiros Conillon. XXIII Congresso Brasileiro de Cafeicultura, Resumo, p.2, Poço de Caldas, MG.

13. Mircetich, S. M., Lowe, S. K., Moller, W. J., and Nyland, G. 1976. Etiology of almond leaf scorch disease and isolation of the causal agent. Phytopathology 66:17-24.

14. Paradela Filho, O., Sugimori, M. H., Ribeiro, I. J. A., Machado, M. A., Laranjeira, F. F., Garcia, A., Jr., Beretta, M. J. G., Harakawa, R., Rodriques Neto, J., and Beriam, L. O. S. 1995. Primeira constatação em cafeeiro no Brasil da Xylella fastidiosa causadora da clorose variegada dos citros. LARANJA 16(2):127-134

15. Pooler, M. R., and Hartung, J. S. 1995. Specific PCR detection and identification of Xylella fastidiosa strains causing citrus variegated chlorosis. Curr. Microbiol. 31: 377-381.

16. Prato, J. R. A. 2000. Quem diria, a Xylella fastdiosa sempre esteve no café. A Granja, fevereiro/2000, $\mathrm{N}^{\circ}$ 614:40-43.
17. Rosato, Y B., Neto, J. R. Miranda, V. S Carlos, E. F., and Manfio, G. P. 1998. Diversity of a Xylella fastidiosa population isolated from Citrus sinensis affected by citrus variegated chlorosis in Brazil. Syst. Appl. Microbiol. 21(4):593-598.

18. Rossetti, V., Garnier, M., Bové, J. M., Beretta, M. J. G., Teixeira, A. R. R., Quagio, J. A., and De Negri, J. D. 1990. Presencé de bacteries dans le Xyléme d'oranges atteint de chlorose variegée, une nouvelle malade des agrumes au Brésil. C. R. Acad. Sci. 310(3):345-349.

19. Sherald, J. L. 1993. Pathogenicity of Xylella fastidiosa in American elm and failure of reciprocal transmission between strains from elm and sycamore. Plant Dis. 77:190-193.

20. Wells, J. M., Raju, B. C., Huang, H., Weilburg, W. G., Mandelco-Paul, L., and Brenner, D. J. 1987. Xylella fastidiosa gen. Nov., sp. Nov: gram-negative, xylem-limited, fastidious plant bacteria related to Xanthomonas spp. Int. J. Syst. Bacteriol. 37(2):136-143.

21. Wells, J. M., Raju, B. C., Thomson, J. M., and Lowe, S. K. 1981. Evidence of the common etiology of phony peach and plum leaf scald diseases. Phytopathology 71:1156-1161. 